\title{
Occurrence of Ehrlichia canis and Hepatozoon canis and probable exposure to Rickettsia amblyommatis in dogs and cats in Natal, RN
}

\author{
Ocorrência de Ehrlichia canis, Hepatozoon canis e provável exposição a Rickettsia amblyommatis \\ em cães e gatos de Natal, RN
}

Marcos Gomes Lopes ${ }^{1}$; Felipe da Silva Krawczak ${ }^{1,2}$; Julia Teresa Ribeiro de Lima ${ }^{1}$;

Gislene Fatima da Silva Rocha Fournier ${ }^{1}$; Igor da Cunha Lima Acosta ${ }^{1}$; Diego Garcia Ramirez ${ }^{1}$; Arlei Marcili ${ }^{1,3}$; Marcelo Bahia Labruna ${ }^{1}$; Solange Maria Gennari ${ }^{1,3 *}$

\footnotetext{
${ }^{1}$ Departamento de Medicina Veterinária Preventiva e Saúde Animal, Faculdade de Medicina Veterinária e Zootecnia, Universidade de Sáo Paulo - USP, São Paulo, SP, Brasil

${ }^{2}$ Setor de Medicina Veterinária Preventiva, Escola de Veterinária e Zootecnia, Universidade Federal de Goiás - UFG, Goiânia, GO, Brasil

${ }^{3}$ Mestrado em Medicina e Bem-Estar Animal, Universidade Santo Amaro - UNISA, São Paulo, SP, Brasil
}

Received June 14, 2018

Accepted July 23, 2018

\begin{abstract}
Occurrence of infection or exposure to Ehrlichia canis, Hepatozoon canis and Rickettsia spp. was detected in feral cats living in two fragments from Atlantic rainforest, in Natal, RN, Brazil, and in dogs living around the parks. While serum samples were collected from 155 animals (53 cats living in the parks; 29 dogs living in human homes around the parks; and 73 dogs living at an animal control center - ACC), spleen samples were collected from 20 dogs that were euthanized at ACC. Serum samples were analyzed to Rickettsia spp. and E. canis antibodies using the indirect immunofluorescence assay. Seventeen of the 102 dogs (17\%) had E. canis antibodies and 13\% (20/155) of all dogs and cats (i.e. 3\% (3/102) of the dogs and 32\% (17/53) of the cats) were seropositive for Rickettsia spp. antigens. The animals were therefore been exposed to $R$. amblyommatis or by a very closely related genotype. Among the $20 \mathrm{dog}$ spleen samples analyzed, eight were PCR positive for E. canis and two for H. canis (GenBank accession number MG772657 and MG772658, respectively). In none of the spleen samples were obtained amplicons for Babesia spp. through PCR. This study provided the first evidence that Rickettsia of the spotted fever group is circulating among dogs and cats in Natal.
\end{abstract}

Keywords: R. amblyommatis, PCR, IFA, Atlantic rainforest, Brazil.

\section{Resumo}

A ocorrência de infecção ou exposição para Ehrlichia canis, Hepatozoon canis e Ricketts ia spp. foi determinada em gatos ferais que viviam em dois fragmentos da Mata Atlântica, localizados em Natal, RN, Brasil e em cáes que viviam em torno dos parques e em outras regiōes da cidade. Enquanto amostras de soro foram coletadas de 155 animais (53 gatos que viviam nos parques, 29 cães com domicilio em torno dos parques e 73 cáes do Centro de Controle de Animais -CCA), fragmentos de baço foram coletados de 20 cáes eutanasiados no CCA. A detecção de anticorpos nas amostras de soros coletadas contra Rickettsia spp. e E. canis foi realizada pela Reação de Imunofluorescência Indireta. Dezessete dos 102 cáes (17\%) apresentaram anticorpos anti E. canis e 13\% (20/155) de todos os cáes e gatos (ou seja, $3 \%$ (3/102) dos cáes e 32\% (17/53) dos gatos) foram soropositivos para antígenos de Rickettsia spp. Os animais foram considerados expostos à $R$. amblyommatis ou a um genótipo muito relacionado. Entre as 20 amostras de baço de cáes analisadas, oito foram positivas para E. canis e duas para Hepatozoon canis (números de acesso ao Genbank MG772657 e MG772658, respectivamente). Nenhuma das amostras de baço produziram amplicons de Babesia spp. na PCR. Observou-se, pela primeira vez, a circulação de Rickettsia do grupo da febre maculosa em cáes e gatos em Natal, RN.

Palavras-chave: $R$. amblyommatis, PCR, RIFI, Mata Atlântica, Brasil.

*Corresponding author: Solange Maria Gennari. Departamento de

Medicina Veterinária Preventiva e Saúde Animal, Universidade de São Paulo

- USP, Av. Prof. Dr. Orlando Marques de Paiva, 87, Cidade Universitária,

CEP 05508-270, São Paulo, SP, Brasil. e-mail: sgennari@usp.br 


\section{Introduction}

Dogs and cats are very popular as pets around the world and can be reservoirs for many microorganisms. Ehrlichia canis, Hepatozoon canis and Rickettsia of the spotted fever group (SFG) may cause diseases in dogs that develop either subclinical infection or severe clinical signs (HARRUS \& WANER, 2011, in review; GONDIM et al., 1998; PIRANDA et al., 2008; STILES, 2000). However, the information on clinical signs showing by cats infected by tick-borne agents remains contradictory and requires further characterization (FRITZ \& KJEMTRUP, 2003; SHAW et al., 2001). These agents have been reported infecting dogs in many parts of Brazil at wide ranges of occurrence and prevalence rates (COSTA et al., 2015; MIRANDA et al., 2014; KRAWCZAK et al., 2012; RAMOS et al., 2010; ROTONDANO et al., 2015, 2017; SAITO et al., 2008; SILVA et al., 2010; VIEIRA et al., 2011).

Wild carnivores inhabiting natural areas in periurban locations may be infected by the same pathogens that infect dogs and cats at higher infection rates (MILLÁN et al., 2016). Definition of the reservoirs and vectors involved in the transmission routes is an important step towards prevention of zoonoses.

In this study, we attempted to detect the occurrence of Babesia spp., Ehrlichia canis, Hepatozoon canis and Rickettsia spp. in feral cats living in two forest fragments located in the Atlantic Rainforest biome, in the municipality of Natal, state of Rio Grande do Norte (RN), Brazil, and in dogs living around the parks and in other regions of the city.

\section{Materials and Methods}

\section{Study area and sample collection}

For this study, feral cats living in two forest fragments within the Atlantic Rainforest Biome, in Natal, RN, Brazil, were selected: Parque Estadual das Dunas de Natal (Natal Dunes State Park; $5^{\circ} 49^{\prime} 41^{\prime \prime} \mathrm{S}$ and $\left.35^{\circ} 11^{\prime} 25^{\prime \prime} \mathrm{W}\right)$ and Parque da Cidade (City Park; $5^{\circ} 50^{\prime} 45^{\prime \prime} \mathrm{S}$ and $\left.35^{\circ} 14^{\prime} 0^{\prime \prime} \mathrm{W}\right)$. In addition, we sampled the population of dogs living in homes located around the parks and dogs at the Animal Control Center (ACC) of the city of Natal, which held dogs from several city regions.

Feral short hair cats were caught manually. These cats were found living in the parks without any care provided and in a state of uncontrolled reproduction, abandoned there by citizens. Apparently healthy dogs, living in their owners' homes around the parks, were sampled by convenience in these homes, according to the accessibility of the place. The dogs at the ACC were euthanized for a variety of reasons, and samples were collected on these occasions.

All the blood samples were collected from the cephalic or jugular vein. The blood serum from each animal was stored separately in microtubes at $-20^{\circ} \mathrm{C}$ until the laboratory analyses were performed. Some ticks that were found parasitizing the animals were collected and taken to the laboratory for taxonomic identification. The ticks were taxonomically identified following dichotomous keys: Martins et al. (2010) for nymphs; Barros-Battesti et al. (2006) for adults.

\section{Serological analyses}

Canine serum samples were tested individually by means of the indirect immunofluorescence assay (IFA) using $E$. canis-infected DH82 cells as the antigen. The São Paulo strain of E. canis was used for this, as previously described (AGUIAR et al., 2007, 2008). Reactions were performed using fluorescein-conjugated rabbit anti-dog IgG diluted 1:1000 (Sigma-Aldrich, St. Louis, MO, USA). Serum was considered to contain antibodies reactive to E. canis if it displayed a reaction at the dilution 1:80. Samples that reacted at the screening dilution $(1: 80)$ were then titrated using serial twofold dilutions to determine endpoint titers. The positive and negative control serum samples were derived from the study by Aguiar et al. (2007).

Feline and canine antibodies reactive to Rickettsia spp. were assayed by simultaneously using six Rickettsia isolates from Brazil: $R$. bellii strain Mogi, $R$ amblyommatis strain Ac37, R. rhipicephali strain $\mathrm{HJ} 5, R$. rickettsii strain Taiaçu, $R$. parkeri strain At24, and Rickettsia felis strain Pedreira, as previously described (LABRUNA et al., 2007a). Samples that reacted at the screening dilution (1:64) were then titrated using serial twofold dilutions to determine endpoint titers. Fluorescein isothiocyanate-labeled conjugate goat anti-cat IgG, or rabbit anti-dog IgG diluted 1:1000 (Sigma, St Louis, USA) were used. To determine the probable homologous antigens (PHA), serum showing a Rickettsia species reactive titer at least four-fold higher than those observed for the other Rickettsia species was taken to be homologous to the first Rickettsia species or to a very closely related genotype (LABRUNA et al., 2007b; PIRANDA et al., 2008). As control, a dog and cat serum previously shown to be non-reactive (negative controls) and known reactive serum samples (positive control) were used (HORTA et al., 2007). These samples were obtained from the serum bank of the Laboratory of Parasitic Diseases, Department of Preventive Veterinary Medicine and Animal Health (VPS), School of Veterinary Medicine and Animal Science (FMVZ), University of São Paulo (USP).

\section{Molecular analyses}

DNA was extracted from dog spleen fragments of approximately 20mg each, using the Wizard ${ }^{\circledR}$ genomic DNA purification kit (Promega Corporation, Madison, Wisconsin, USA), in accordance with the manufacturer's instructions. DNA samples were tested by Polymerase Chain Reaction (PCR) using the sets of primers described in Table 1. Reactions were performed in a final volume of $25 \mu \mathrm{l}$ containing $10 \mathrm{mM}$ of Tris- $\mathrm{HCl}(\mathrm{pH} 8.3), 50 \mu \mathrm{M}$ of $\mathrm{KCl}$, $1.5 \mathrm{mM}$ of $\mathrm{MgCl}_{2}, 0.2 \mathrm{mM}$ of each desoxynucleoside triphosphate, $1.5 \mathrm{U}$ of Taq DNA polymerase (Invitrogen), $11 \mathrm{pmol}$ of each primer and approximately $100 \mathrm{\eta g}$ of canine genomic DNA. The amplified products were viewed under ultraviolet light after electrophoresis on agarose gel $(1.5 \%)$ stained with $\mathrm{SyBr}$ gold (Invitrogen). The PCR products were purified using ExoSap (USB) and were sequenced in an automatic sequencer (model ABI Prism 310 Genetic; Applied Biosystems/Perkin Elmer, California, USA), in accordance with the manufacturer's protocol, and with the same primers as used in the PCR. The partial sequences obtained were 
subjected to BLAST analyses (ALTSCHUL et al., 1990) to infer the closest similarities to sequences in GenBank.

\section{Results}

Between October 2012 and August 2013, four campaigns were conducted, and serum samples were collected from 155 animals: 53 feral cats (Felis catus) living in the parks; 29 dogs (Canis familiaris) living in human homes around the parks; and 73 dogs at the ACC. Furthermore, spleen fragments from 20 dogs that were euthanized at the ACC were also collected.

The serological results showed that $17 \%$ (17/102) of the dogs showed anti-E. canis antibodies and 13\% (20/155) of all the animals tested, i.e. 3\% (3/102) of the dogs and 32\% (17/53) of the cats, were seropositive for Rickettsia spp. antigens (Table 2), with endpoint titers ranging from 64 to 2048 (Table 3). Except for one dog serum that only showed $R$. bellii as the PHA, and one cat serum that showed $R$. parkeri as the PHA, all the other positive animals showed seroreactivity with the highest titers for $R$. amblyommatis. At least 13 animals presented $R$. amblyommatis as the PHA, for which endpoint titers were four-fold higher than the endpoint titers shown for the other five Rickettsia species. These 13 animals might have been exposed to $R$. amblyommatis or a very closely related genotype (Table 3 ).

Parasitism by ticks of the species Rhipicephalus sanguineus sensu lato (s.l.) was observed in 38\% (11/29) of the dogs, Park ${ }^{1}$ 23,5\% (4/17) and $\operatorname{Park}^{2} 58,3 \%$ (7/12). One cat (2\% [1/49]) from
Parque da Cidade was found to be parasitized by one nymph stage of Amblyomma auricularium.

Among the 20 dog spleen samples, subjected to molecular analyses, eight were found to be positive in the PCR targeting a fragment of the 16S rRNA gene of Anaplasmataceae, and in the PCR targeting a fragment of the $d s b$ gene of Ehrlichia spp. PCR products of $16 S \mathrm{rRNA}$ and $d s b$ gene generated sequences $100 \%$ similarity to $E$. canis, which is found in several parts of the world, including Brazil (16S rRNA: KP642752, KP182941, KP182942; dsb: MG967467, KY594915, CP025749, KR920044). Furthermore, two samples were positive for Hepatozoon canis, which were confirmed by DNA sequences and BLAST analysis, showing to be $100 \%$ identity to sequences already reported from dogs around the world (KJ513193, KJ513198, KF621083). None of the canine spleen samples yielded amplicons in the PCR for Babesia spp.

DNA sequences generated in this study were deposited in GenBank under the accession numbers MH118746 for E. canis 16S rRNA partial sequence, MG772657 for E. canis dsb partial sequence, and MG772658 for $H$. canis $18 \mathrm{~S}$ rRNA partial sequence.

\section{Discussion}

The results from the serological analyses on Rickettsia spp. showed that the number of seropositive dogs was low (3\%), while it was relatively high (32\%) among the sampled cats (Table 2). This can possibly be explained by the fact that the cats were living inside the parks and were exposed to parasitism by $A$. auricularium,

Table 1. Primer pairs used in the present study for detecting tick-borne agents.

\begin{tabular}{|c|c|c|c|c|}
\hline $\begin{array}{l}\text { Target agents } \\
\text { (gene) }\end{array}$ & Primers & Primer sequences (5'-3') & $(\mathbf{B p})$ & Reference \\
\hline $\begin{array}{l}\text { Babesia spp. } \\
\text { (18S rRNA) }\end{array}$ & $\begin{array}{l}\mathrm{BAB} 1 \\
\mathrm{BAB} 4\end{array}$ & $\begin{array}{l}\text { GTGAACCTTATCACTTAAAGG } \\
\text { CAACTCCTCCACGCAATCG }\end{array}$ & 590 & Duarte et al. (2008) \\
\hline $\begin{array}{l}\text { Anaplasmataceae } \\
\text { (16S rRNA) }\end{array}$ & $\begin{array}{l}\mathrm{GE} 2^{\prime} \mathrm{F} 2^{\prime} \\
\mathrm{HE} 3\end{array}$ & $\begin{array}{c}\text { GTTAGTGGCAGACGGGTGAGT } \\
\text { TATAGGTACCGTCATTATCTTCCCTAT }\end{array}$ & 360 & Aguiar et al. (2008) \\
\hline $\begin{array}{l}\text { Ehrlichia spp. } \\
\text { (dsb gene) }\end{array}$ & $\begin{array}{l}\text { DSB-330 } \\
\text { DSB-728 }\end{array}$ & $\begin{array}{l}\text { GATGATGTCTGAAGATATGAAACAAAT } \\
\text { CTGCTCGTCTATTTTACTTCTTAAAGT }\end{array}$ & 409 & Doyle et al. (2005) \\
\hline $\begin{array}{l}\text { Hepatozoon sp. } \\
\text { (18S rRNA) }\end{array}$ & $\begin{array}{l}\text { HEP2-169 } \\
\text { HEP2-718 }\end{array}$ & $\begin{array}{l}\text { F- GGTAATTCTAGAGCTAATACATGAGC } \\
\text { R- ACAATAAAGTAAAAAACAYTTCAAAG }\end{array}$ & 574 & Almeida et al. (2012) \\
\hline
\end{tabular}

$\mathrm{Bp}=$ Base Pairs.

Table 2. Distribution according to area of the numbers of dogs and cats in the state of Rio Grande do Norte, Brazil, that were analyzed for Rickettsia spp. and E. canis using the indirect immunofluorescence assay (IFA), showing the numbers of positive cases and percentages.

\begin{tabular}{ccc}
\hline Animals & \multicolumn{2}{c}{ No. seropositive animals / No. tested (\% seropositivity) } \\
\cline { 2 - 3 } IFA for Rickettsia spp. & \multicolumn{1}{c}{ IFA for . canis } \\
\hline Felis catus $\left(\operatorname{Park}^{1}\right)$ & $1 / 4(25)$ & Not tested \\
Felis catus $\left(\operatorname{Park}^{2}\right)$ & $16 / 49(33)$ & $3 / 102(3 \%)$ \\
Canis familiaris $\left(\operatorname{Park}^{1}\right)$ & $1 / 17(6)$ & $5 / 17(25)$ \\
Canis familiaris $\left(\operatorname{Park}^{2}\right)$ & $2 / 12(16)$ & $3 / 12(25)$ \\
Canis familiaris $(\mathrm{ACC})$ & $0 / 73(0)$ & $9 / 73(12)$ \\
Total & $20 / 155(13)$ & $17 / 102(17)$ \\
\hline
\end{tabular}

\footnotetext{
${ }^{1}$ Parque Estadual das Dunas de Natal; ${ }^{2}$ Parque da Cidade; ACC $=$ animal control center.
} 
Table 3. Results from indirect immunofluorescence assays (IFA) against six Rickettsia species among serum samples from dogs and cats in Natal, Rio Grande do Norte, Brazil.

\begin{tabular}{|c|c|c|c|c|c|c|c|}
\hline \multirow{2}{*}{ Animals IDs } & \multicolumn{7}{|c|}{ Endpoint titers for rickettsial antigens } \\
\hline & R. ambly ${ }^{1}$ & R. riphi ${ }^{2}$ & R. rick ${ }^{3}$ & R. parke $e^{4}$ & R. belli 5 & R. felis ${ }^{6}$ & PHA $^{7}$ \\
\hline Dog $10\left(\operatorname{park}^{1}\right)$ & 0 & 0 & 0 & 0 & 256 & 0 & R. belli \\
\hline $\operatorname{Dog} 23\left(\right.$ park $\left.^{2}\right)$ & 1024 & 0 & 0 & 0 & 0 & 0 & R. ambly \\
\hline Dog $25\left(\right.$ park $\left.^{2}\right)$ & 512 & 0 & 0 & 0 & 64 & 0 & R. ambly \\
\hline Cat $33\left(\right.$ park $\left.^{2}\right)$ & 256 & 0 & 0 & 0 & 0 & 0 & R. ambly \\
\hline Cat $5\left(\operatorname{park}^{2}\right)$ & 64 & 0 & 0 & 64 & 0 & 0 & - \\
\hline Cat $8\left(\operatorname{park}^{2}\right)$ & 64 & 0 & 0 & 0 & 0 & 0 & - \\
\hline Cat $19\left(\right.$ park $\left.^{2}\right)$ & 2048 & 512 & 256 & 256 & 128 & 64 & R. ambly \\
\hline Cat $20\left(\right.$ park $\left.^{2}\right)$ & 1024 & 0 & 0 & 0 & 0 & 0 & R. ambly \\
\hline Cat 9 (28.2) $\left(\right.$ park $\left.^{2}\right)$ & 512 & 0 & 0 & 0 & 0 & 0 & R. ambly \\
\hline Cat 6 (1.3) ( park $\left.^{2}\right)$ & 2048 & 256 & 256 & 0 & 256 & 0 & R. ambly \\
\hline Cat $35\left(\right.$ park $\left.^{2}\right)$ & 256 & 0 & 0 & 0 & 0 & 0 & R. ambly \\
\hline Cat $24\left(\right.$ park $\left.^{2}\right)$ & 1024 & 0 & 0 & 0 & 0 & 0 & R. ambly \\
\hline Cat $23\left(\right.$ park $\left.^{2}\right)$ & 512 & 0 & 0 & 0 & 0 & 0 & R. ambly \\
\hline Cat $32\left(\right.$ park $\left.^{2}\right)$ & 64 & 0 & 0 & 0 & 0 & 0 & - \\
\hline Cat $7\left(\right.$ park $\left.^{2}\right)$ & 0 & 0 & 0 & 64 & 0 & 0 & - \\
\hline Cat 9 (park $\left.{ }^{2}\right)$ & 512 & 256 & 0 & 1024 & 0 & 0 & - \\
\hline Cat $11\left(\right.$ park $\left.^{2}\right)$ & 256 & 0 & 0 & 0 & 0 & 0 & R. ambly \\
\hline Cat 1 (1.3) ( park $\left.^{1}\right)$ & 1024 & 0 & 0 & 0 & 0 & 0 & R. ambly \\
\hline Cat 31( park $\left.^{2}\right)$ & 512 & 0 & 0 & 0 & 0 & 0 & R. ambly \\
\hline Cat 9 (18.2) $\left(\right.$ park $\left.^{2}\right)$ & 0 & 0 & 0 & 256 & 0 & 0 & R. parke \\
\hline
\end{tabular}

${ }^{1}$ Rickettsia amblyommatis; ${ }^{2} R$. rhipicephali; ${ }^{3} R$. rickettsii; ${ }^{4} R$. parkeri; ${ }^{5} R$. bellii; ${ }^{6} R$. felis; ${ }^{7} \mathrm{PHA}=$ probable homologous antigens; park ${ }^{1}=$ Parque Estadual das Dunas de Natal; park $^{2}$ = Parque da Cidade.

as observed on this work. It is known that this tick is a competent vector for $R$. amblyommatis (SARAIVA et al., 2013). Moreover, two dogs living in the area around the parks showed antibodies against $R$. amblyommatis while the dogs at the ACC were all negative. In a previous study in the state of Sáo Paulo, Horta et al. (2007) showed that cats could be better rickettsial sentinels than dogs. Cats may be more exposed to ticks than other domestic animals because of their habits. In the present study, the cats abandoned in the parks had become feral, living in direct contact with the wild environment.

The importance of $R$. amblyommatis in relation to pathogenicity for humans is not yet fully elucidated. However, some Rocky Mountain spotted fever (RMSF) cases in the United States that were diagnosed as due to $R$. rickettsii may have instead been due to $R$. amblyommatis (APPERSON et al., 2008).

The IFA test showed that antibodies for $E$. canis were found in $17 \%(17 / 102)$ of the dogs analyzed in this study. A similar seropositivity rate was previously observed by Costa et al. (2015), who found antibodies to this agent in $14.6 \%$ of the dogs from rural and urban areas of the state of Maranhão, Brazil. Higher seropositivity rates among dogs have been reported in studies conducted in other states in northeastern Brazil: Paraíba 72.5\%, 69.4\%, 23\% and 34\% (ARAES-SANTOS et al., 2015; AZEVEDO et al., 2011; ROTONDANO et al., 2015; TANIKAWA et al., 2013); and Bahia 23.0\%, 36\% and 35.6\% (ARAES-SANTOS et al., 2015; CARLOS et al., 2007; SOUZA et al., 2010).

Confirming the serological findings, E. canis DNA was detected by PCR in 40\% (8/20) of the canine spleen samples.
Furthermore, 75\% (6/8) of these PCR-positive dogs were also positive in serological analysis for E. canis antibodies. Previous studies in the state of Rio Grande do Norte showed results that corroborate the findings of the present study: fragments of DNA sequences of $E$. canis and $H$. canis were detected in blood samples collected from dogs in the city of Mossoró (GONÇALVES et al., 2014). Furthermore, inclusions suggestive of Ehrlichia spp. were detected in $6.5 \%(13 / 198)$ of dogs showing clinical signs suggestive of canine monocytic ehrlichiosis in the same city (MEDEIROS \& LIMA, 2004). These results revealed that E. canis was the main tick-borne pathogen infecting dogs in northeastern Brazil, a condition corroborated by the present study.

In Brazil, Hepatozoon canis infection has been reported in many regions and the occurrence rate may range from $8.6 \%$ to $100 \%$ in the southeastern region (MIRANDA et al., 2014; MUNDIM et al., 2008; O'DWYER et al., 2001; SPOLIDORIO et al., 2009) and $3.6 \%$ to $73 \%$ in the central-western region (MELO et al., 2016; MUNDIM ECS. et al., 2008; PALUDO et al., 2003; RAMOS et al., 2015), while two cases with molecular analyses has been reported in the southern region (LASTA et al., 2009; MALHEIROS et al., 2016). Studies in northeastern Brazil have shown lower occurrence rates ranging from $0.49 \%$ in Pernambuco to $9.3 \%$ in Paraiba (BERNARDINO et al., 2016; RAMOS et al., 2010; ROTONDANO et al., 2015). Gonçalves et al. (2014) reported $H$. canis infection cases in Mossoro, RN. Our results strengthen the data on circulation of this parasite in this study region through showing that $10 \%(2 / 20)$ of the dog spleen samples were positive for $H$. canis by means of PCR. 
Rhipicephalus sanguineus s.l. was the only tick species found on the dogs evaluated in this study. This Ixodidae is a competent vector for E. canis (DANTAS-TORRES, 2008) corroborating with the serological and molecular results of the present study.

In conclusion, Rickettsia spp., represented mainly by anti- $R$. amblyommatis antibodies, are circulating among cats and dogs in the anthropized fragments of the Atlantic Rainforest biome in the municipality of Natal, RN, Brazil. Cats were shown to be an important sentinel for Rickettsia spp., and E. canis and $H$. canis are also infecting dogs in the urban area of Natal. To our knowledge, the present study provided the first evidence suggesting that Rickettsia of the spotted fever group is circulating among dogs and cats in the region analyzed here in the state of Rio Grande do Norte, northeastern Brazil.

\section{Acknowledgements}

This work was supported by FAPESP (2012/02556-3 Fundação de Amparo à Pesquisa do Estado de São Paulo) and CAPES.

\section{References}

Aguiar DM, Hagiwara MK, Labruna MB. In vitro isolation and molecular characterization of an Ehrlichia canis strain from São Paulo, Brazil. Braz J Microbiol 2008; 39(3): 489-493. http://dx.doi.org/10.1590/S151783822008000300014. PMid:24031251.

Aguiar DM, Saito TB, Hagiwara MK, Machado RZ, Labruna M. Diagnóstico sorológico de erliquiose canina com antígeno brasileiro de Ehrlichia canis. Cienc Rural 2007; 37(3): 796-802. http://dx.doi. org/10.1590/S0103-84782007000300030.

Almeida AP, Marcili A, Leite RC, Nieri-Bastos FA, Domingues LN, Martins JR, et al. Coxiella symbiont in the tick Ornithodoros rostratus (Acari: Argasidae). Ticks Tick Borne Dis 2012; 3(4): 203-206. http:// dx.doi.org/10.1016/j.ttbdis.2012.02.003. PMid:22480930.

Altschul SF, Gish W, Miller W, Myers EW, Lipman DJ. Basic local alignment search tool. J Mol Biol 1990; 215(3): 403-410. http://dx.doi. org/10.1016/S0022-2836(05)80360-2. PMid:2231712.

Apperson CS, Engber B, Nicholson WL, Mead DG, Engel J, Yabsley MJ, et al. Tick-borne diseases in North Carolina: is "Rickettsia amblyommii" a possible cause of rickettsiosis reported as Rocky Mountain spotted fever? Vector Borne Zoonotic Dis 2008; 8(5): 597-606. http://dx.doi. org/10.1089/vbz.2007.0271. PMid:18447622.

Araes-Santos AI, Moraes-Filho J, Peixoto RM, Spolidorio MG, Azevedo SS, Costa MM, et al. Ectoparasite Infestations and Canine Infection by Rickettsiae and Ehrlichiae in a Semi-Arid Region of Northeastern Brazil. Vector Borne Zoonotic Dis 2015; 15(11): 645-651. http://dx.doi. org/10.1089/vbz.2015.1786. PMid:26565771.

Azevedo SS, Aguiar DM, Aquino SF, Orlandelli RO, Fernandes ARF, Uchôa ICP. Soroprevalência e fatores de risco associados à soropositividade para Ehrlichia canis em cães do semiárido da Paraíba. Braz J Vet Res Anim Sci 2011; 48(1): 14-18. http://dx.doi.org/10.11606/S141395962011000100002 .

Barros-Battesti DM, Arzua M, Bechara GH. Carrapatos de importância médico-veterinária da região neotropical: um guia ilustrado para identificação de espécies. São Paulo: Vox/ ICTTD-3/Butantan; 2006.
Bernardino MGS, Meireles MVN, Silva EG, Xavier FJR, Satake F. Prevalência de hepatozoonose canina no município de Areia, Paraíba, Brasil. Biotemas 2016; 29(1): 175-179. http://dx.doi.org/10.5007/21757925.2016v29n1p175.

Carlos RSA, Muniz Neta ES, Spagnol FH, Oliveira LS, Brito RLL, Albuquerque GR, et al. Freqüência de anticorpos anti-Erhlichia canis, Borrelia burgdorferi e antígenos de Dirofilaria immitis em cães na microrregiāo Ilhéus-Itabuna, Bahia, Brasil. Rev Bras Parasitol Vet 2007; 16(3): 117-120. http://dx.doi.org/10.1590/S1984-29612007000300001. PMid:18078596.

Costa AP, Costa FB, Labruna MB, Silveira I, Moraes-Filho J, Soares JF, et al. A serological and molecular survey of Babesia vogeli, Ehrlichia canis and Rickettsia spp. among dogs in the state of Maranhão, northeastern Brazil. Rev Bras Parasitol Vet 2015; 24(1): 28-35. http://dx.doi.org/10.1590/ S1984-29612015008. PMid:25909250.

Dantas-Torres F. Canine vector-borne diseases in Brazil. Parasit Vectors 2008; 1(1): 25. http://dx.doi.org/10.1186/1756-3305-1-25. PMid:18691408.

Doyle CK, Labruna MB, Breitschwerdt EB, Tang Y, Corstvet RE, Hegarty BC, et al. Detection of medically important Ehrlichia by quantitative multicolor TaqMan real-time polymerase chain reaction of the $d s b$ gene. J Mol Diagn 2005; 7(4): 504-510. http://dx.doi.org/10.1016/S15251578(10)60581-8. PMid:16237220.

Duarte SC, Linhares GF, Romanowsky TN, Silveira OJ No, Borges LM. Assessment of primers designed for the subspecies-specific discrimination among Babesia canis canis, Babesia canis vogeli and Babesia canis rossi by PCR assay. Vet Parasitol 2008; 152(1-2): 16-20. http://dx.doi.org/10.1016/j. vetpar.2007.12.013. PMid:18242863.

Fritz CL, Kjemtrup AM. Lyme borreliosis. J Am Vet Med Assoc 2003; 223(9): 1261-1270. http://dx.doi.org/10.2460/javma.2003.223.1261. PMid:14621212.

Gonçalves LR, Filgueira KD, Ahid SMM, Pereira JS, Vale AM, Machado $\mathrm{RZ}$, et al. Study on coinfecting vector-borne pathogens in dogs and ticks in Rio Grande do Norte, Brazil. Rev Bras Parasitol Vet 2014; 23(3): $407-$ 412. http://dx.doi.org/10.1590/S1984-29612014071. PMid:25271465.

Gondim LF, Kohayagawa A, Alencar NX, Biondo AW, Takahira RK, Franco SR. Canine hepatozoonosis in Brazil: description of eight naturally occurring cases. Vet Parasitol 1998; 74(2-4): 319-323. http://dx.doi. org/10.1016/S0304-4017(96)01120-X. PMid:9561717.

Harrus S, Waner T. Diagnosis of canine monocytotropic ehrlichiosis (Ehrlichia canis): an overview. Vet J2011; 187(3): 292-296. http://dx.doi. org/10.1016/j.tvjl.2010.02.001. PMid:20226700.

Horta MC, Labruna MB, Pinter A, Linardi PM, Schumaker TTS. Rickettsia infection in five areas of the state of São Paulo, Brazil. Mem Inst Oswaldo Cruz 2007; 102(7): 793-801. http://dx.doi.org/10.1590/ S0074-02762007000700003. PMid:18094887.

Krawczak FS, Labruna MB, Sangioni LA, Vogel FSF, Soares JF, Lopes STA. Serological survey on Ehrlichia sp. among dogs in the central region of Rio Grande do Sul. Rev Bras Parasitol Vet 2012; 21(4): 415-417. http:// dx.doi.org/10.1590/S1984-29612012005000001. PMid:23184320.

Labruna MB, Horta MC, Aguiar DM, Cavalcante GT, Pinter A, Gennari SM, et al. Prevalence of Rickettsia infection in dogs from the urban and rural areas of Monte Negro Municipality, Western Amazon, Brazil. Vector Borne Zoonotic Dis 2007b; 7(2): 249-255. http://dx.doi.org/10.1089/ vbz.2006.0621. PMid:17627445.

Labruna MB, Pacheco RC, Richtzenhain LJ, Szabó MP. Isolation of Rickettsia rhipicephali and Rickettsia bellii from Haemaphysalis juxtakochi 
Ticks in the State of São Paulo, Brazil. Appl Environ Microbiol 2007a; 73(3): 869-873. http://dx.doi.org/10.1128/AEM.02249-06. PMid:17142361.

Lasta CS, Santos AP, Mello FPS, Lacerda LA, Messick JB, Díaz González FH. Infecção por Hepatozoon canis em canino doméstico na regiāo Sul do Brasil confirmada por técnicas moleculares. Cienc Rural 2009; 39(7): 2135-2140. http://dx.doi.org/10.1590/S0103-84782009005000160.

Malheiros J, Costa MM, do Amaral RB, de Sousa KCM, André MR, Machado RZ, et al. Identification of vector-borne pathogens in dogs and cats from Southern Brazil. Ticks Tick Borne Dis 2016; 7(5): 893900. http://dx.doi.org/10.1016/j.ttbdis.2016.04.007. PMid:27266811.

Martins TF, Onofrio VC, Barros-Battesti DM, Labruna MB. Nymphs of the genus Amblyomma (Acari: Ixodidae) of Brazil: descriptions, redescriptions, and identification key. Ticks Tick Borne Dis 2010; 1(2): 75-99. http://dx.doi.org/10.1016/j.ttbdis.2010.03.002. PMid:21771514.

Medeiros AMM, Lima AKF. Ocorrência de ehrlichiose canina em Mossoró. Ciênc Anim 2004; 14(1): 53-57.

Melo ALT, Witter R, Martins TF, Pacheco TA, Alves AS, Chitarra CS, et al. A survey of tick-borne pathogens in dogs and their ticks in the Pantanal biome, Brazil. Med Vet Entomol 2016; 30(1): 112-116. http://dx.doi. org/10.1111/mve.12139. PMid:26467462.

Millán J, Proboste T, Fernández de Mera IG, Chirife AD, de la Fuente J, Altet L. Molecular detection of vector-borne pathogens in wild and domestic carnivores and their ticks at the human-wildlife interface. Ticks Tick Borne Dis 2016; 7(2): 284-290. http://dx.doi.org/10.1016/j. ttbdis.2015.11.003. PMid:26643497.

Miranda RL, O’Dwyer LH, de Castro JR, Metzger B, Rubini AS, Mundim $\mathrm{AV}$, et al. Prevalence and molecular characterization of Hepatozoon canis in dogs from urban and rural areas in Southeast Brazil. Res Vet $S_{c i}$ 2014; 97(2): 325-328. http://dx.doi.org/10.1016/j.rvsc.2014.06.015. PMid:25039064.

Mundim AV, Morais IA, Tavares M, Cury MC, Mundim MJ. Clinical and hematological signs associated with dogs naturally infected by Hepatozoon sp. and with other hematozoa: a retrospective study in Uberlândia, Minas Gerais, Brazil. Vet Parasitol 2008; 153(1-2): 3-8. http://dx.doi. org/10.1016/j.vetpar.2008.01.018. PMid:18304739.

Mundim ECS, Silva Francisco MM, Souza JN, Alencar MA, Dias Ramalho PC. Incidência de hemoparasitoses em cães (Canis familiares) de rua capturados pelo Centro de Controle de Zoonoses (CCZ) da cidade de Anápolis-GO. Ensaios Cienc: Cienc Biol. Agrária Saúde 2008; 12(2): 107-115.

O’Dwyer LH, Massard CL, Pereira de Souza JC. Hepatozoon canis infection associated with dog ticks of rural areas of Rio de Janeiro State, Brazil. Vet Parasitol 2001; 94(3): 143-150. http://dx.doi.org/10.1016/ S0304-4017(00)00378-2. PMid:11113545.

Paludo GR, Dell'Porto A, Castro e Trindade AR, McManus C, Friedman H. Hepatozoon spp.: report of some cases in dogs in Brasília, Brazil. Vet Parasitol 2003; 118(3-4): 243-248. http://dx.doi.org/10.1016/j. vetpar.2003.10.009. PMid:14729172.

Piranda EM, Faccini JL, Pinter A, Saito TB, Pacheco RC, Hagiwara $\mathrm{MK}$, et al. Experimental infection of dogs with a Brazilian strain of Rickettsia rickettsii: clinical and laboratory findings. Mem Inst Oswaldo Cruz 2008; 103(7): 696-701. http://dx.doi.org/10.1590/S007402762008000700012 . PMid:19057821.
Ramos CA, Babo-Terra VJ, Pedroso TC, Souza AF Fo, Ribeiro de Araújo F, Cleveland HP. Molecular identification of Hepatozoon canis in dogs from Campo Grande, Mato Grosso do Sul, Brazil. Rev Bras Parasitol Vet 2015; 24(2): 247-250. http://dx.doi.org/10.1590/S1984-29612015019. PMid:26154969.

Ramos R, Ramos C, Araújo F, Oliveira R, Souza I, Pimentel D, et al. Molecular survey and genetic characterization of tick-borne pathogens in dogs in metropolitan Recife (north-eastern Brazil). Parasitol Res 2010 107(5): 1115-1120. http://dx.doi.org/10.1007/s00436-010-1979-7. PMid:20680344.

Rotondano TE, Almeida HK, Krawczak FS, Santana VL, Vidal IF, Labruna $\mathrm{MB}$, et al. Survey of Ehrlichia canis, Babesia spp. and Hepatozoon spp. in dogs from a semiarid region of Brazil. Rev Bras Parasitol Vet 2015; 24(1): 52-58. http://dx.doi.org/10.1590/S1984-29612015011. PMid:25909253.

Rotondano TE, Krawczak FS, Barbosa WO, Moraes-Filho J, Bastos FN, Labruna MB, et al. Ehrlichia canis and Rickettsia spp. in dogs from urban areas in Paraiba state, northeastern Brazil. Rev Bras Parasitol Vet 2017; 26(2): 211-215. http://dx.doi.org/10.1590/s1984-29612017030. PMid:28658415.

Saito TB, Cunha-Filho NA, Pacheco RC, Ferreira F, Pappen FG, Farias NA, et al. Canine infection by rickettsiae and ehrlichiae in southern Brazil. Am J Trop Med Hyg 2008; 79(1): 102-108. PMid:18606772.

Saraiva DG, Nieri-Bastos FA, Horta MC, Soares HS, Nicola PA, Pereira LC, et al. Rickettsia amblyommii infecting Amblyomma auricularium ticks in Pernambuco, Northeastern Brazil: isolation, transovarial transmission, and transstadial perpetuation. Vector Borne Zoonotic Dis 2013; 13(9): 615-618. http://dx.doi.org/10.1089/vbz.2012.1223. PMid:23705586.

Shaw SE, Birtles RJ, Day MJ. Arthropod-transmitted infectious diseases of cats. J Feline Med Surg 2001; 3(4): 193-209. http://dx.doi.org/10.1053/ jfms.2001.0149. PMid:11795958.

Silva JN, Almeida ABPF, Boa Sorte EC, Freitas AG, Santos LGF, Aguiar $\mathrm{DM}$, et al. Soroprevalência de anticorpos anti-Ehrlichia canis em cáes de Cuiabá, Mato Grosso. Rev Bras Parasitol Vet 2010; 19(2): 108-111. http:// dx.doi.org/10.1590/S1984-29612010000200008. PMid:20624348.

Souza BMPS, Leal DC, Barboza DCPM, Uzêda RS, Alcântara ACD, Ferreira F, et al. Prevalence of ehrlichial infection among dogs and ticks in Northeastern Brazil. Rev Bras Parasitol Vet 2010; 19(2): 89-93. http:// dx.doi.org/10.1590/S1984-29612010000200004. PMid:20624344.

Spolidorio MG, Labruna MB, Zago AM, Donatele DM, Caliari KM, Yoshinari NH. Hepatozoon canis infecting dogs in the State of Espírito Santo, southeastern Brazil. Vet Parasitol 2009; 163(4): 357-361. http:// dx.doi.org/10.1016/j.vetpar.2009.05.002. PMid:19482427.

Stiles J. Canine rickettsial infections. Vet Clin North Am Small Anim Pract 2000; 30(5): 1135-1149. http://dx.doi.org/10.1016/S01955616(00)05011-7. PMid:11033879.

Tanikawa A, Labruna MB, Costa A, Aguiar DM, Justiniano SV, Mendes RS, et al. Ehrlichia canis in dogs in a semiarid region of Northeastern Brazil: Serology, molecular detection and associated factors. Res Vet Sci 2013; 94(3): 474-477. http://dx.doi.org/10.1016/j.rvsc.2012.10.007. PMid:23141416.

Vieira RFC, Biondo AW, Guimarães AMS, Santos AP, Santos RP, Dutra LH, et al. Ehrlichiosis in Brazil. Rev Bras Parasitol Vet 2011; 20(1): 1-12. http://dx.doi.org/10.1590/S1984-29612011000100002. PMid:21439224. 